\title{
Organometallic Phosphinimines as Building Blocks for Potential New Radiopharmaceuticals. Synthesis, Structure and Reactivity of $\mathrm{Ph}_{3} \mathrm{P}=\mathrm{NH}_{2}{ }^{+} \mathrm{ReO}_{4}{ }^{-}$
}

\author{
Kattesh V. Katti*a,d, Prahlad R. Singh ${ }^{\mathrm{a}, \mathrm{c}}$, Charles L. Barnes ${ }^{\mathrm{b}}$, Kavita K. Kattia,c, \\ Karel Kopicka ${ }^{\mathrm{d}}$, Alan R. Ketring ${ }^{\mathrm{d}}$, and Wynn A. Volkert ${ }^{\mathrm{c}, \mathrm{e}}$ \\ Center for Radiological Research ${ }^{\mathrm{a}}$, Departments of Chemistry ${ }^{\mathrm{b}}$ and Radiology $\mathrm{y}^{\mathrm{c}}$, \\ Missouri University Research Reactor Center d, University of Missouri-Columbia and \\ Research Service, H. S. Truman Memorial VA Hospitale, Columbia, Missouri, U.S.A. \\ Z. Naturforsch. 48b, 1381 -1385 (1993); received January 15/June 18, 1993 \\ Phosphinimines, Radiopharmaceuticals, X-Ray, Nuclear Medicine, Radio-Rhenium \\ Reactions of the organometallic phosphinimine $\mathrm{Ph}_{3} \mathrm{P}=\mathrm{N}-\mathrm{SiMe}_{3}(\mathbf{1})$, with aqueous $\mathrm{ReO}_{4}$ \\ and ${ }^{188} \mathrm{ReO}_{4}^{-}$yield the ion pairs $\mathrm{Ph}_{3} \mathrm{P}=\mathrm{NH}_{2}{ }^{+} \mathrm{MO}_{4}^{-}\left(\mathrm{M}=\mathrm{Re}(2) ;{ }^{188} \mathrm{Re}(\mathbf{4})\right)$. The ion pairs under- \\ go dehydration upon heating to produce the neutral $\mathrm{Re}(\mathrm{VII})$ species: $\mathrm{Ph}_{3} \mathrm{P}=\mathrm{N}-\mathrm{MO}_{3}(\mathrm{M}=\mathrm{Re}$ \\ (3); $\left.{ }^{188} \mathrm{Re}(5)\right)$. The solid state structure of $\mathrm{Ph}_{3} \mathrm{P}=\mathrm{NH}_{2}{ }^{+} \mathrm{ReO}_{4}^{-}(2)$ shows the presence of hy- \\ drogen bonding between the iminato hydrogen and the rhenium oxo center. The relevance \\ of such reactions for the design of new radiopharmaceuticals is discussed.
}

\section{Introduction}

There is a resurgence of interest in the use of organometallic phosphinimines (e.g.; $\mathrm{Ph}_{3} \mathrm{P}=\mathrm{N}-\mathrm{SiMe}_{3}(\mathbf{1})$ ) as novel ligand systems for transition metals and actinide metals [1]. Phosphinimines of the type $\mathbf{1}$ have shown versatility in their ability to donate 1,2 , or 4 electrons to transition metals to produce kinetically stable compounds with most early transition metals. The N-Silylphosphinimines of the type $\mathbf{1}$ are prolific in their reactions with metal precursors because reactions with the metal halides proceeds through the facile elimination of $\mathrm{Me}_{3} \mathrm{SiX}$, whereas, metal oxides also react smoothly through the migration of $\mathrm{Me}_{3} \mathrm{Si}$ from the iminato nitrogen onto the oxygen of the metal center. Despite the diversity in structure and reactivity of phosphinimines as noted above, there are no reports of the reactions of this class of ligand systems with metallic radioisotopes. The development of fundamental coordination chemistry of rhenium and technetium continue to make significant impact in the discovery of new radiopharmaceuticals of radiorhenium and technetium- $99 \mathrm{~m}$ for applications in nuclear medicine. A number of different ligand systems which include macrocyclic amines [2], aminethiols [3], amidethiols [4], isocyanides [5], boronic acid derivatives [6], phosphines [7], phos-

* Reprint requests to Dr. K. V. Katti.

Verlag der Zeitschrift für Naturforschung, D-72072 Tübingen

0932-0776/93/1000-1381/\$ 01.00/0 phonates [8] and many other ligand frameworks [9] have been used in the past to produce stable complexes of radiorhenium and technetium. In this communication, we report the use of an organometallic phosphinimine, $\mathrm{Ph}_{3} \mathrm{P}=\mathrm{N}-\mathrm{SiMe}_{3}$ (1), to produce complexes of rhenium $\mathrm{Ph}_{3} \mathrm{P}=\mathrm{NH}_{2}{ }^{+} \mathrm{ReO}_{4}$ (2) and $\mathrm{Ph}_{3} \mathrm{P}=\mathrm{N}-\mathrm{ReO}_{3}$ (3) and also the corresponding ${ }^{188} \mathrm{Re}$ analogues $\mathrm{Ph}_{3} \mathrm{P}=\mathrm{NH}_{2}{ }^{+188} \mathrm{ReO}_{4}^{-}$(4) and $\mathrm{Ph}_{3} \mathrm{P}=\mathrm{N}^{188} \mathrm{ReO}_{3}$ (5).

\section{Results and Discussion}

We have investigated the reaction of $\mathrm{Ph}_{3} \mathrm{P}=\mathrm{N}-\mathrm{SiMe}_{3}(\mathbf{1})$ with $\mathrm{NH}_{4}{ }^{+} \mathrm{ReO}_{4}{ }^{-}$with the intent of extending the chemistry to the corresponding tetraoxo anion of ${ }^{188} \mathrm{Re}$ and ${ }^{99 \mathrm{~m}} \mathrm{Tc}$ [10]. Aqueous solutions of $\mathrm{NH}_{4} \mathrm{ReO}_{4}$ on treatment with a solution of $\mathrm{Ph}_{3} \mathrm{P}=\mathrm{N}-\mathrm{SiMe}_{3}$ (1) in $\mathrm{CH}_{3} \mathrm{CN}$ resulted in a near quantitative yield of the ion pair $\mathrm{Ph}_{3} \mathrm{P}=\mathrm{NH}_{2}{ }^{+} \mathrm{ReO}_{4}^{-}$(2) (Scheme 1) which was isolated as a colorless crystalline solid upon recrystallization from $\mathrm{CH}_{3} \mathrm{CN}$. Analytical, spectroscopic $\left({ }^{31} \mathrm{P}\right.$ NMR and IR) data and single crystal X-ray crystallographic analysis (Fig. 1) confirmed its chemical constitution.

The structure reveals the presence of hydrogen bonding between the iminato hydrogens and the oxygen atoms of the $\mathrm{ReO}_{4}^{-}$anion. The $\mathrm{P}-\mathrm{N}$ bond length (1.636(7) $\AA$ ) (Table I) found in the $\operatorname{Re}(\mathrm{VII})$ ion pair $\mathbf{2}$ is within the range observed for a recently reported non-metallated free phosphinimine ion pair of the type: $\mathrm{R}_{2} \mathrm{R}^{\prime} \mathrm{P}=\mathrm{NH}_{2}{ }^{+} \mathrm{Cl}$ [11]. The absence of any significant elongation of the $\mathrm{P}-\mathrm{N}$ bond in 2 


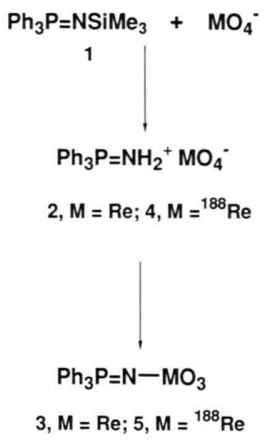

Scheme 1 .

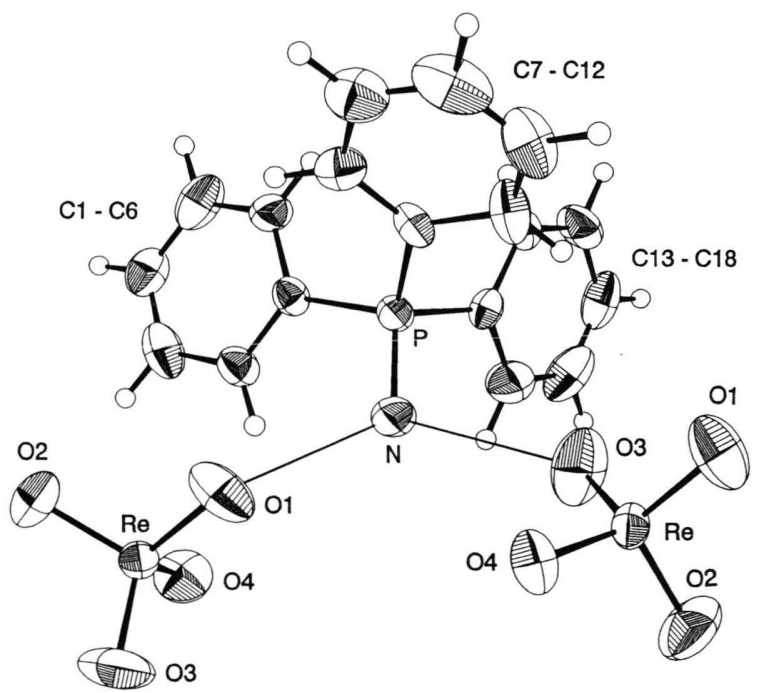

Fig. 1. ORTEP drawing of $\mathrm{Ph}_{3} \mathrm{P}=\mathrm{NH}_{2}{ }^{+} \mathrm{ReO}_{4}{ }^{-}$(4) showing $50 \%$ thermal ellipsoids. The interaction between $\mathrm{O}(1)$ or $\mathrm{O}(3)$ and the imine $\mathrm{N}$ is through hydrogen bonding.

as compared to the free phosphinimine may suggest some delocalization of electronic charge from the $\mathrm{Re}(\mathrm{VII})$ center onto the $\mathrm{P}-\mathrm{N}$ bond. This is further indicated by the fact that the $\mathrm{P}-\mathrm{N}$ bond length in $\mathbf{2}$ is very similar to the $\mathrm{P}-\mathrm{N}$ bond lengths reported for a number of phosphinimine complexes of early transition metals [1]. The ion pair is soluble in ethyl alcohol and other common organic solvents (e.g., $\mathrm{CHCl}_{3}$, toluene and THF). The addition of water to the $\mathrm{CH}_{3} \mathrm{CN}$ solutions of 2 (1:1) did not result in the dissociation of the ion pair and such solutions also did not show a temperature dependency of the ${ }^{31} \mathrm{P}$ NMR chemical shifts. The ion pair $\mathbf{2}$ has a sharp melting point of $160{ }^{\circ} \mathrm{C}$ and remelts without decomposition at the same temperature. It is nonhygroscopic and can be stored in an open atmos-
Table I. Selected bond distances $[\AA ̊]$ and angles $\left[{ }^{\circ}\right]$.

Distances

$\begin{array}{ll}\mathrm{Re}-\mathrm{O}(1) & 1.710(8) \\ \mathrm{Re}-\mathrm{O}(2) & 1.690(7) \\ \mathrm{Re}-\mathrm{O}(2) & 1.699(8) \\ \mathrm{Re}-\mathrm{O}(2) & 1.727(7) \\ \mathrm{P}-\mathrm{N} & 1.636(7) \\ \mathrm{P}-\mathrm{C}(1) & 1.794(8) \\ \mathrm{P}-\mathrm{C}(7) & 1.769(8) \\ \mathrm{P}-\mathrm{C}(13) & 1.806(8)\end{array}$

Angles

\begin{tabular}{ll}
$\mathrm{O}(1)-\mathrm{Re}-\mathrm{O}(2)$ & $108.7(4)$ \\
$\mathrm{O}(1)-\mathrm{Re}-\mathrm{O}(3)$ & $112.3(5)$ \\
$\mathrm{O}(1)-\mathrm{Re}-\mathrm{O}(4)$ & $108.3(4)$ \\
$\mathrm{O}(2)-\mathrm{Re}-\mathrm{O}(3)$ & $108.9(5)$ \\
$\mathrm{O}(2)-\mathrm{Re}-\mathrm{O}(4)$ & $108.9(4)$ \\
$\mathrm{O}(3)-\mathrm{Re}-\mathrm{O}(4)$ & $109.6(4)$ \\
$\mathrm{N}-\mathrm{P}-\mathrm{C}(1)$ & $107.3(4)$ \\
$\mathrm{N}-\mathrm{P}-\mathrm{C}(7)$ & $114.3(4)$ \\
$\mathrm{N}-\mathrm{P}-\mathrm{C}(13)$ & $107.0(4)$ \\
$\mathrm{C}(1)-\mathrm{P}-\mathrm{C}(7)$ & $111.0(4)$ \\
$\mathrm{C}(1)-\mathrm{P}-\mathrm{C}(13)$ & $108.4(3)$ \\
$\mathrm{C}(7)-\mathrm{P}-\mathrm{C}(13)$ & $108.6(4)$ \\
$\mathrm{P}-\mathrm{C}(1)-\mathrm{C}(2)$ & $119.8(6)$ \\
$\mathrm{P}-\mathrm{C}(1)-\mathrm{C}(6)$ & $119.8(6)$ \\
$\mathrm{P}-\mathrm{C}(7)-\mathrm{C}(8)$ & $118.1(7)$ \\
$\mathrm{P}-\mathrm{C}(7)-\mathrm{C}(12)$ & $124.1(7)$ \\
$\mathrm{P}-\mathrm{C}(13)-\mathrm{C}(14)$ & $119.4(6)$ \\
$\mathrm{P}-\mathrm{C}(13)-\mathrm{C}(18)$ & $119.7(7)$ \\
\hline
\end{tabular}

phere for months. The dual neutral and ionic type of solubility properties, the melting behavior and the unusual stability of this salt in alcohol is noteworthy. The toluene or acetonitrile solution of 2 upon boiling for 4-6h produced the neutral $\mathrm{Re}(\mathrm{VII})$ phosphinimine complex $\mathrm{Ph}_{3} \mathrm{P}=\mathrm{N}-\mathrm{ReO}_{3}$ (Scheme 1) in near quantitative yields. The neutral complex 3 was also obtained in $60 \%$ yield by heating the solid ion pair 2 in vacuo at $185^{\circ} \mathrm{C}$ for $1.5 \mathrm{~h}$. The electron impact mass spectrum of $\mathbf{3}$ showed the parent ion $(510 ; 80 \%)$ and the solution molecular weight measurements of $\mathbf{3}$ revealed that it is monomeric in solution.

Roesky et al. have reported an approach to the formation of $\mathbf{3}$ in $38 \%$ yield from the reaction of $\mathrm{Ph}_{3} \mathrm{P}=\mathrm{N}-\mathrm{SiMe}_{3}$ with $\mathrm{Re}_{2} \mathrm{O}_{7}$ [12]. Our methodology to produce $\mathbf{3}$ serves as a model to extend the reactions of $\mathrm{Ph}_{3} \mathrm{P}=\mathrm{N}-\mathrm{SiMe}_{3}$ with the tetraoxo anions of ${ }^{99 \mathrm{~m}} \mathrm{Tc}$ or ${ }^{188} \mathrm{Re}$. The extension of this chemistry to produce the ${ }^{99 \mathrm{~m}} \mathrm{Tc}$ or ${ }^{188} \mathrm{Re}$ analogues of $\mathbf{2}$ and $\mathbf{3}$ would also be worthwhile in the context of developing organic soluble ${ }^{99 \mathrm{~m}} \mathrm{Tc}$ or ${ }^{188} \mathrm{Re}$.

Simple mixing of an aqueous solution of ${ }^{188} \mathrm{ReO}_{4}^{-}$ with a $\mathrm{CH}_{3} \mathrm{CN}$ solution of $\mathrm{Ph}_{3} \mathrm{P}=\mathrm{N}-\mathrm{SiMe}_{3}(\mathbf{1})$ at 
$25^{\circ} \mathrm{C}$ produced the ${ }^{188} \mathrm{Re}$ analogue of the ion pair 2 in $98 \%$ yields (Scheme 1). Upon heating the toluene extract of $\mathrm{Ph}_{3} \mathrm{P}=\mathrm{NH}_{2}{ }^{+188} \mathrm{ReO}_{4}{ }^{-}$(4), at $80^{\circ} \mathrm{C}$ for $30 \mathrm{~min}$ the tracer level analogue of $\mathbf{3}$, $\mathrm{Ph}_{3} \mathrm{P}=\mathrm{N}^{188} \mathrm{ReO}_{3}(5)$, was obtained in $>95 \%$ yields. The ion pair and the neutral complex 5 were found to be quite stable in dry toluene with minimal or no decomposition occurring for up to $18 \mathrm{~h}$. The TLC $R_{f}$ values of 5 matched closely with those of its nontracer analogue 3. The TLC $R_{f}$ values (Table I) for $\mathbf{2}$ and its ${ }^{188} \mathrm{Re}$ analogue $\mathbf{4}$ are in perfect agreement to indicate that the species formed at the tracer level is indeed the one identified to be $\mathrm{Ph}_{3} \mathrm{P}=\mathrm{NH}_{2}{ }^{+} \mathrm{ReO}_{4}^{-}$at the non-tracer level. The thin layer chromatographic scanning of 4 and 5 eluted in acetone and ethyl acetate showed sharp single peaks which indicate that both the ion pair and the neutral complexes of ${ }^{188} \mathrm{Re}$ were singular chemical species. The complexes are generally insoluble in aqueous media because they contain three phenyl groups bound to phosphorus.

\section{Conclusions}

${ }^{99} \mathrm{mTc}$ and ${ }^{188} \mathrm{Re}$ are commonly used radioisotopes for diagnosis and therapy of cancer in nuclear medicine. In most parts of the world these two radioisotopes are readily available in their tetraoxo anion (i.e., $\mathrm{MO}_{4}^{-}$) form. The direct interaction of $\mathrm{MO}_{4}^{-}\left(\mathrm{M}=\mathrm{Re}\right.$ and $\left.{ }^{188} \mathrm{Re}\right)$ with an organometallic phosphinimine to produce a complex of radiorhenium as demonstrated in this communication, may set a new trend in the application of unconventional ligand systems in the development of a new generation of radiopharmaceuticals. The substitutional chemistry of the tetrahedral $\mathrm{P}(\mathrm{V})$ center in $\mathbf{1}$ is extensive and such tuning of substituents on the phosphorus may become the most practical approach to develop new classes of radiopharmaceuticals with improved biolocalization and biodistribution characteristics.

\section{Experimental}

The trimethylsilylphosphinimine $\mathrm{Ph}_{3} \mathrm{P}=\mathrm{N}-\mathrm{SiMe}_{3}$ (1) was prepared according to reported procedures [13]. $\mathrm{NH}_{4} \mathrm{ReO}_{4}$ was used as supplied by Aldrich U.S.A. $\mathrm{NH}_{4}{ }^{+188} \mathrm{ReO}_{4}{ }^{-}$was obtained from a ${ }^{188} \mathrm{~W} / 188 \mathrm{Re}$ generator as supplied by the University of Missouri Research Reactor.
Preparation of $\mathrm{Ph}_{3} \mathrm{P}=\mathrm{NH}_{2}{ }^{+} \mathrm{ReO}_{4}{ }^{-}$(2)

To a $\mathrm{CH}_{3} \mathrm{CN}(100 \mathrm{ml})$ solution of $\mathrm{Ph}_{3} \mathrm{P}=\mathrm{N}-\mathrm{SiMe}_{3}$ (1) $(4.11 \mathrm{~g}, 11.77 \mathrm{mmol})$ was added an aqueous solution $(10 \mathrm{ml})$ of $\mathrm{NH}_{4} \mathrm{ReO}_{4}(3.15 \mathrm{~g}, 11.77 \mathrm{mmol})$ dropwise at $25^{\circ} \mathrm{C}$. The mixture was stirred for $1 \mathrm{~h}$ before the volatiles and the aqueous solvents were removed in vacuo to produce a white crystalline solid of $\mathrm{Ph}_{3} \mathrm{P}=\mathrm{NH}_{2}{ }^{-} \mathrm{ReO}_{4}{ }^{-}$(2). The final purification of 2 was achieved by recrystallization from $\mathrm{CH}_{3} \mathrm{CN}$; cooling the solutions to $0^{\circ} \mathrm{C}$ produced cubic shaped X-ray quality crystals of $2(86 \%)$, m.p. $160^{\circ} \mathrm{C} .{ }^{31} \mathrm{P}$ NMR $\left(\mathrm{CDCl}_{3} ; 85 \% \mathrm{H}_{3} \mathrm{PO}_{4}\right) \delta 35.10$; IR (Nujol) $v \mathrm{NH}_{2} 3176 \mathrm{~cm}^{-1}$.

Analysis

Calcd C 40.89 H 3.20 N 2.65\%,

Found C 40.85 H 3.15 N $2.62 \%$.

Preparation of $\mathrm{Ph}_{3} \mathrm{P}=\mathrm{N}-\mathrm{ReO}_{3}(\mathbf{3})$

A solution of $2(2.55 \mathrm{~g}, 5.0 \mathrm{mmol})$ in acetonitrile $(100 \mathrm{ml})$ was heated under reflux for $6 \mathrm{~h}$ before the solvent was removed in vacuo to obtain a colorless solid of $\mathrm{Ph}_{3} \mathrm{P}=\mathrm{N}-\mathrm{ReO}_{3}(3)$. Recrystallization of 3 from $\mathrm{CH}_{3} \mathrm{CN}$ produced analytically pure 3 . Yield $78 \%$; m.p. $192^{\circ} \mathrm{C}$ (decomp.), Lit. m.p. [27] $193^{\circ} \mathrm{C}$ (decomp.). ${ }^{31} \mathrm{P} \mathrm{NMR}\left(\mathrm{CDCl}_{3} ; 85 \% \mathrm{H}_{3} \mathrm{PO}_{4}\right) \delta 38.2$.

\section{Analysis for $\mathrm{C}_{18} \mathrm{H}_{15} \mathrm{NPReO}_{3}$ \\ Calcd C 42.35 H 2.96 N 2.74\%, \\ Found C 42.29 H 2.93 N 2.72\%.}

Roesky et al. [12] have independently reported the formation of $\mathbf{3}\left(\delta^{31} \mathrm{P}=37.9\right)$ in $38 \%$ yield from the reaction of $\mathrm{Re}_{2} \mathrm{O}_{7}$ with $\mathrm{Ph}_{3} \mathrm{P}=\mathrm{N}-\mathrm{SiMe}_{3}$.

\section{Preparation of $\mathrm{Ph}_{3} \mathrm{P}=\mathrm{NH}_{2}^{+188} \mathrm{ReO}_{4}^{-}$(4)}

Typically the ${ }^{188}$ Re complex was prepared by mixing $100 \mu \mathrm{Ci}(370 \mathrm{kBq})$ of ${ }^{188} \mathrm{ReO}_{4}{ }^{-}$in a $0.1 \mathrm{ml}$ saline solution with $\mathrm{Ph}_{3} \mathrm{P}=\mathrm{N}-\mathrm{SiMe}_{3}(\mathbf{1})(10-15 \mathrm{mg})$ in a $1 \mathrm{ml}$ toluene solution. The mixture was vortexed for $1 \mathrm{~min}$ at r.t. $5 \mathrm{~min}$ following vortexing, an aliquot of the organic layer was removed and the radiochemical purity (RCP) of the ${ }^{188} \mathrm{Re}$ complex 2 was measured. Caution: Rhenium- 188 is a $\beta$ emitter $(\mathrm{E}=1.12$ $\mathrm{MeV} ; \mathrm{t}_{1 / 2}=17 \mathrm{~h}$ ). All work has been done in laboratories approved for the use of radioactive materials.

\section{Preparation of $\mathrm{Ph}_{3} \mathrm{P}=\mathrm{N}-{ }^{188} \mathrm{ReO}_{3}(\mathbf{5})$}

A toluene extract of $\mathrm{Ph}_{3} \mathrm{P}=\mathrm{NH}_{2}{ }^{+188} \mathrm{ReO}_{4}^{-}(2 \mathrm{ml}$; $100-150 \mu \mathrm{Ci}$ ) was heated at $80^{\circ} \mathrm{C}$ for $30 \mathrm{~min}$. An aliquot of the solution was used to determine the radiochemical purity (RCP) (95\%) of $\mathrm{Ph}_{3} \mathrm{P}=\mathrm{N}-{ }^{188} \mathrm{ReO}_{3}$ by radiographic scanning methods as described below. 
Table II. TLC $R_{f}$ values for $\mathrm{Re}^{\mathrm{a}}-$ and ${ }^{188} \mathrm{Re}^{\mathrm{b}}$-phosphiniminato complexes.

\begin{tabular}{llll}
\hline & & \multicolumn{2}{c}{$R_{f}$ values } \\
Complex & Acetone & Saline & Ethyl acetate \\
\hline $\mathrm{NH}_{4}{ }^{+} \mathrm{ReO}_{4}^{-}$ & 0.97 & 0.90 & 0.0 \\
$\mathrm{Ph}_{3} \mathrm{P}=\mathrm{NH}_{2}{ }^{+} \mathrm{ReO}_{4}^{-}$ & 0.85 & 0.88 & 0.80 \\
$\mathrm{Ph}_{3} \mathrm{P}=\mathrm{NH}_{2}{ }^{+188} \mathrm{ReO}_{4}^{-}$ & 0.86 & 0.88 & 0.80 \\
$\mathrm{Ph}_{3} \mathrm{P}=\mathrm{N}-\mathrm{ReO}_{3}$ & 0.82 & 0.0 & 0.75 \\
$\mathrm{Ph}_{3} \mathrm{P}=\mathrm{N}-{ }^{188} \mathrm{ReO}_{3}$ & 0.82 & 0.0 & 0.73 \\
\hline
\end{tabular}

${ }^{a} R_{f}$ values determined by conventional TLC chromatography; ${ }^{\mathrm{b}} R_{f}$ values determined by radiographic scanning of the chromatographic strips (see Experimental for details).

\section{Chromatographic and radiographic scanning studies}

The radiochemical purity (RCP) of the ${ }^{188} \mathrm{Re}$ complexes were determined by paper chromatography (PC) and on instant thin layer chromatographysilica gel (ITLC-SG). PC and ITLC-SG analysis involved spotting $10 \mu \mathrm{l}$ of the complex near the bottom (origin) of the strips. The strips were then developed in $0.9 \%$ aqueous saline, ethyl acetate and acetone. Determination of the $R_{f}$ 's and quantitation of the migration of activity on the paper strips were made using AMBIS radiochromatographic scanning system and/or by cutting $1 \mathrm{~cm}$ sections of the strips and counting each section in a NaI well counter. The RCP's of the samples at r.t. were measured for $24 \mathrm{~h}$ to study their stability as a function of time. The complexes were formed in typically $>95 \%$ yields and showed no significant decomposition over a period of $24 \mathrm{~h}$. Blanks of ${ }^{188} \mathrm{ReO}_{4}^{-}$were done on PC and ITLC-SG. Typically, $\mathrm{NH}_{4}{ }^{+188} \mathrm{ReO}_{4}^{-}$ showed an $R_{f}$ of 0.97 in acetone, an $R_{f}$ of 0.00 in ethyl acetate and an $R_{f}$ of 0.9 in saline on both paper and thin layer-silica gel strips.

\section{Single crystal $X$-ray structural analysis of $\mathrm{Ph}_{3} \mathrm{P}=\mathrm{NH}_{2}{ }^{+} \mathrm{ReO}_{4}^{-}{ }^{-}$(2)}

Crystal data for $\mathrm{C}_{18} \mathrm{H}_{15} \mathrm{NPReO}_{4}$ (4): orthorhombic P 2,2,2 (No. 19), $a=11.1809$ (9); $b=11.4598(11)$; $c=14.5957(9) \AA ; \mathrm{V}=1870.2(3) \AA^{3} ; Z=4 ; \mathrm{D}_{\text {calcd }}=$ $1.870 \mathrm{~g} \mathrm{~cm}^{-3}, \lambda(\mathrm{MoK} \alpha)=0.70930 \AA, \mu=6.69 \mathrm{~mm}^{-1}$. An Enraf-Nonius CAD-4 diffractometer was used to collect 3622 independent reflections on a colorless cubic shaped crystal. Of these 3215 were observed $(\mathrm{I} \geq 2.5 \sigma(\mathrm{I}))$. The structure was solved by direct methods. All non-hydrogen atoms were refined anisotropically. The hydrogen atoms were included in idealized positions. $\mathrm{R}=0.029, R_{\mathrm{w}}=0.042$.
Table III. Atomic parameters $x, y, z$ and $\mathrm{B}_{\text {iso }}$. E.S.Ds. refer to the last digit printed.

\begin{tabular}{lllll}
\hline & $x$ & $y$ & $z$ & $B_{\text {iso }}$ \\
\hline Re & $0.34177(3)$ & $0.28070(3)$ & $0.138223(19)$ & $2.762(14)$ \\
O1 & $0.1892(7)$ & $0.2718(7)$ & $0.1340(6)$ & $5.9(4)$ \\
O2 & $0.3844(9)$ & $0.2918(9)$ & $0.2489(5)$ & $6.5(4)$ \\
O3 & $0.3952(9)$ & $0.3975(8)$ & $0.0794(6)$ & $6.7(4)$ \\
O4 & $0.4003(7)$ & $0.1539(7)$ & $0.0927(5)$ & $5.0(3)$ \\
P & $0.99840(16)$ & $0.97329(15)$ & $0.14356(13)$ & $2.57(7)$ \\
N & $1.0577(6)$ & $1.0640(7)$ & $0.0699(5)$ & $3.6(3)$ \\
C1 & $1.1111(7)$ & $0.9397(7)$ & $0.2270(5)$ & $2.6(3)$ \\
C2 & $1.2295(7)$ & $0.9675(7)$ & $0.2097(6)$ & $3.4(3)$ \\
C3 & $1.3169(9)$ & $0.9346(9)$ & $0.2751(8)$ & $4.7(4)$ \\
C4 & $1.2841(9)$ & $0.8739(8)$ & $0.3496(7)$ & $4.0(4)$ \\
C5 & $1.1647(10)$ & $0.8439(10)$ & $0.3660(6)$ & $4.8(5)$ \\
C6 & $1.0798(8)$ & $0.8752(8)$ & $0.3055(6)$ & $3.5(3)$ \\
C7 & $0.8667(7)$ & $1.0253(7)$ & $0.1969(6)$ & $3.1(3)$ \\
C8 & $0.7591(9)$ & $1.0257(8)$ & $0.1449(8)$ & $4.3(4)$ \\
C9 & $0.6579(9)$ & $1.0754(9)$ & $0.1816(10)$ & $5.2(5)$ \\
C10 & $0.6602(10)$ & $1.1189(8)$ & $0.2679(11)$ & $5.8(6)$ \\
C11 & $0.7585(10)$ & $1.1206(9)$ & $0.3205(9)$ & $5.0(5)$ \\
C12 & $0.8633(9)$ & $1.0741(8)$ & $0.2839(6)$ & $3.7(3)$ \\
C13 & $0.9627(7)$ & $0.8414(7)$ & $0.0816(5)$ & $2.8(3)$ \\
C14 & $0.8765(8)$ & $0.7665(7)$ & $0.1160(6)$ & $3.2(3)$ \\
C15 & $0.8571(9)$ & $0.6593(8)$ & $0.0739(7)$ & $4.3(4)$ \\
C16 & $0.9229(12)$ & $0.6310(8)$ & $-0.0031(6)$ & $5.0(5)$ \\
C17 & $1.0058(14)$ & $0.7029(11)$ & $-0.0369(7)$ & $5.7(5)$ \\
C18 & $1.0277(10)$ & $0.8119(9)$ & $0.0047(7)$ & $4.5(4)$ \\
\hline
\end{tabular}

$\mathrm{B}_{\text {iso }}$ is the mean of the principal axes of the displacement ellipsoid.

The final difference map had maximum and minimum densities of +0.870 and $-1.130 \mathrm{e}^{-3}$, respectively. The positional parameters and their estimated standard deviations are summarized in Table III. Atomic scattering factors and anomalous dispersion corrections were taken from the International Table for X-Ray Crystallography [14]. All calculations were performed with NRCVAX [15].

Further details may be obtained from: Fachinformationszentrum Karlsruhe, Gesellschaft für wissenschaftlich-technische Information $\mathrm{mbH}$, D-76344 Eggenstein-Leopoldshafen, by quoting the Registry-No. CSD 57422, the names of the authors and the journal citation.

\section{Acknowledgement}

This work was supported by funds provided by DOE grant DEFG 0289 E R 60875 and by the Departments of Chemistry, Radiology and Research Reactor, University of Missouri, Columbia, Missouri. 
[1] a) E. A. Abel and S. A. Muckeljohn, Phosphorus Sulfur 9, 125 (1981);

b) K. Dehnicke and J. Strähle, Polyhedron 9, 707 (1989);

c) H. W. Roesky, Synlett 11, 651 (1990);

d) K. Dehnicke and J. Strähle, Angew. Chem., Int. Ed. Engl. 31, 955 (1991);

e) H. W. Roesky, K. V. Katti, U. Scholtz, R. Herbst, E. Egert, and G. M. Sheldrick, Z. Naturforsch. 41 b, 1509 (1986);

f) K. V. Katti, H. W. Roesky, and M. Rietzel, Z. Anorg. Allg. Chem. 123, 553 (1987);

g) H. W. Roesky, U. Seseke, M. Noltemeyer, P. G. Jones, and G. M. Sheldrick, J. Chem. Soc. Dalton Trans. 1986, 1309;

h) K. Dehnicke, H. Prioz, W Kafitz, and R. Kujanek, Liebigs Ann. Chem. 1981, 20;

i) K. V. Katti and R. G. Cavell, Organometallics 8, 2147 (1989);

j) K. V. Katti and R. G. Cavell, Organometallics 7, 2236 (1988);

k) K. V. Katti, R. J. Batchelor, W. B. Einstein, and R. G. Cavell, Inorg. Chem. 29, 808 (1990);

1) K. V. Katti and R. G. Cavell, Comments Inorg. Chem. 10, 53 (1990);

m) K. V. Katti and R. G. Cavell, Organometallics 10, 539 (1991).

[2] a) M. R. A. Pillai, C. S. John, J. Lo, E. O. Schlemper and D. E. Troutner, Inorg. Chem. 29, 1850 (1990);

b) C. Messa, F. Zito, C. Rossetti, F. Colombo, M. Matarrese, G. Taddei, E. Deutsch, G. Lueignani, F. Fazio, J. Nucl. Med. 30, 831 (1989);

c) E. Refosco, F. Tissato, U. Mazzi, G. Bandoli, and M. J. Nocolini, J. Chem. Soc. Dalton Trans. 1988, 611.

[3] a) A. Najafi, M. M. Aluddin, M. M. Siegel, and A. L. Epstein, Nucl. Med. Biol. 18, 2, 179 (1991);

b) K. Shiba, H. Mori, S. Tsuji, K. Kinuya, and K. Hisada, Int. J. Appl. Radiat. Isot. 42,1159 (1991); c) E. M. N. Efange, H. F. Kung, J. Billings, Y.-Z. Guo, and M. Blau, J. Nucl. Med. 28, 1012 (1987);

d) K. E. Baidoo, L. A. Epps, U. Scheffel, H. D. Burns, S. Z. Lever, A. V. Kramer, H. Goldfarb, R. Gungon, and H. H. Wagner (Jr.), J. Nucl. Med. 28, 29 (1987).

[4] a) T. N. Rao, D. Adhikesavalu, A. Camerman, and A. R. Fritzberg, J. Am. Chem. Soc. 112, 5798 (1990); b) A. R. Fritzberg, P. G. Abrams, P. G. Beaumier, S. Kasina, A. C. Morgan, T. N. Rao, J. M. Reno, J. A. Sanderson, A. Srinivasan, S. D. Wilbur, and J. L. Vanderheyden, Proc. Natl. Acad. Sci. U.S.A. 85, 4025 (1988);

c) D. Brenner, A. Davison, S. J. Lister-James, and A. G. Jones, Inorg. Chem. 23, 3793 (1984).

[5] a) F. E. Hahn, M. Tamm, A. D. Klingemann, and R. Neumeier, Chem. Ber. 124, 1683 (1991);

b) J. F. Kronauge, A. Davison, A. M. Roseberry,
C. F. Costello, S. Maleknia, and A. G. Jones, Inorg. Chem. 30, 4265 (1991).

[6] E. N. Treher, L. C. Francesconi, J. Z. Gougoutas, M. F. Malley, and A. D. Nunn, Inorg. Chem. 28, 3411 (1989).

[7] a) P. L. Watson, J. A. Albanesa, J. C. Calabrese, D. W. Ovenall, and R. G. Smith, Inorg. Chem. 30, 4638 (1991);

b) F. Refosco, G. Bandoli, E. A. Deutsch, A. Duatti, U. Mazzi, A. Moresco, M. Nicolini, Technetium and Rhenium in Chemistry and Nuclear Medicine, in M. Nicolini, G. Bandoli, and U. Mazzi (eds): Cortina International, Verona, Italy, 3rd ed., pp. 221 -234 (1990);

c) A. Lahiri, B. Higley, J. C. W. Crawley, K. W. Chiu, B. Edwards, T. Smith, D. V. Griffiths, C. M. Archer, I. A. Latham, and J. D. Kelly, J. Nucl. Med. 30, 818 (1989);

d) P. Gerundini, A. Savi, M. C. Gilardi, A. Margonato, G. Vicedomini, L. Zecca, W. Hirth, K. Libson, J. C. Bhatia, F. Fazio, and E. Deutsch, J. Nucl. Med. 27, 409 (1986).

[8] H. R. Maxon, E. A. Deutsch, S. R. Thomas, J. S. Moulton, L. E. Schroder, K. F. Libson, M. Soldano, C. C. Williams, and D. D. Cummings, J. Nucl. Med. 29, 776 (1988).

[9] a) F. Refosco, C. Bolzatic, A. Moresco, G. Bandoli, A. Dolmella, U. Mazzi, and M. Nicolini, J. Chem. Soc. Dalton Trans. 1991, 3043;

b) R. Tisato, U. Mazzi, G. Bandoli, G. Cros, M. H. Darbieu, Y. Coulair, and R. Guiraud, J. Chem. Soc. Dalton Trans. 1991, 1301;

c) U. Abram, S. Abram, and W. Hiller, Z. Naturforsch. $\mathbf{4 6 ~ b , ~} 456$ (1991);

d) A. Bossuyt and J. R. Thornbacker, J. Nucl. Med. 32, 500 (1991);

e) A. Duatti, A. Marchi, V. Bertolasi, and V. Ferretti, J. Am. Chem. Soc. 113, 9682 (1991).

[10] a) K. V. Katti, C. E. Barnes, Inorg. Chem. 31, 4231 (1992);

b) K. V. Katti, P. R. Singh, K. K. Katti, K. Kopicka, W. A. Volkert, and A. R. Keting, J. Label. Comp. Radiopharm., in press (1993);

c) P. R. Singh, W. A. Volkert, A. R. Ketring, D. E. Troutner, K. K. Katti, and K. V. Katti, J. Label. Comp. Radiopharm., in press (1993).

[11] K. V. Katti, A. A. Pinkerton, and R. G. Cavell, Inorg. Chem. 30, 2631 (1991)

[12] H. W. Roesky, D. Hesse, M. Rietzel, and M. Noltemeyer, Z. Naturforsch. 45 b, 72 (1990).

[13] L. Birkofer, A. Ritter, and P. Richter, Chem. Ber. 96, 2750 (1963).

[14] International Tables for X-Ray Crystallography, Vol. IV, Kynoch Press, Birmingham, U.K. (1974) (present distributor: D. Reidel, Dordrecht, The Netherlands).

[15] E. J. Gasbe, Y. LePage, J.-P. Charland, and F. E. Lee, J. Appl. Crystallogr. 22, 384 (1989). 